\title{
Developing Task-Based Listening-Speaking Materials for Students
}

\author{
Dian Nadia
}

PhD Student, Faculty of Education studies, Brawijaya University, Indonesia

na_dina3@gmail.com

\begin{abstract}
The objectives of this research were to describe the existing listening-speaking materials used in English for Nursing subject in nursing academy and to find out the feasibility of the developed listening-speaking materials for English for Nursing subject. This research belongs to Research and Development (R\&D) study. The steps consisted of needs analysis, designing prototype, developing prototype, expert judgment, and try out. The data were gained through questionnaires, observation, and interviews. The results of this research were listening-speaking materials for nursing academy students with following characteristics: 1) it was developed based on students' needs, 2) it was developed based on TBLT, 3) it contained tasks that enabled the students to learn and practise the language they need in their workplace, especially listening and speaking skills. The draft then was evaluated by ELT and subject experts. The appropriateness of materials was shown in the terms of materials, presentation, illustration, language, and graphic appropriateness. It achieved a final mean score of 3.81, which was in the range of $3.25<\mathrm{x} \leq 4$. After that, the material was tried-out to validate the feasibility. Finally, this material for nursing academy students is expected to meet the students' needs in increasing their listening and speaking skills.
\end{abstract}

Keyword: Listening; Materials; Speaking

\section{Introduction}

A local nursing academy in district level strengthens itself by stating the vision and missions of the institution. One of the missions is to educate the students to be competent nurses. Nurses are regarded as competent when they are skilful, professional, noble, virtuous, and responsive to the advancement. It means the nurses are not only competent in nursing skills but also in seeking the chance to improve the quality of their personal live, including financial and professional career, such as getting job overseas through government to government ( $G$ to $G$ ) program (BNP2TKI, 2015). Therefore, one of efforts in educating the students to be competent nurses is to improve English language mastery, especially listening and speaking skills. 
However, there are some problems occurred in the teaching and learning process. The problems could relate to students, lecturers, facilities, and learning materials. Especially, talking about learning materials, it was found that there was no adequate English for Nursing course book for the students so that the lecturer had to compile, select, and match suitable materials from many resources. In addition, based on the result of field research, it was found that there were some English for Nursing and TOEFL books provided in the library that could enrich the students' input about English for Nursing. However, only the active students accessed the books. Then, the activities in the teaching and learning process were not varied. The students usually were asked to translate and explain the content of a journal about health from English to Bahasa Indonesia and to conduct a simple role-play of patient-nurse conversation.

Next, based on the result of library research, there were some weaknesses of the books provided in the library, in terms of organization, content, and approach used. Some of the weaknesses were the books provided very long conversation model without emphasizing which the language functions or expressions were used, the books did not apply certain approach, and the learning objectives were not clearly stated. Later, the interview with the lecturer yielded the result that the lecturer needed teaching and learning materials for listening and speaking skills that enabled the students to practise the expressions related to their profession, helped the students to improve their English, and contained vocabularies about health and nursing.

By considering the missions of institution, challenge, and the chance in improving English competence, the researcher proposed to design certain materials for teaching English for Nursing, especially for listening and speaking skills using Task Based Language Teaching (TBLT) approach. There were some reasons in selecting TBLT approach in developing this module. First, TBLT has strengthened the following principles and practices: a needs-based approach to content selection, an emphasis on learning to communicate through interaction in the target language, the introduction of authentic texts into the learning of situation, and the linking of classroom language learning with language outside the classroom (Nunan, 2004). Second, Basturkmen (2010) proposed that one of the recommended approaches for teaching ESP (English for Specific Purposes) is TBLT. It was recommended since by using TBLT, the teaching and learning process and the materials taught are designed based on learners' needs. A listening-speaking material with TBLT approach is expected to enable the students to experience the tasks that emphasize the real use of language. In other words, the principles in TBLT approach are suitable for designing the materials based on the learners' needs, as explained by Nunan (2004).

In conclusion, corresponding to the problem described, the objectives of this research were formulated as follows: 1) to describe the existing listening-speaking materials used in English for Nursing subject in nursing academy, 2) to find out the feasibility of the developed English listeningspeaking materials for nursing academy students. 


\section{Literature Review}

\section{English for Specific Purposes (ESP)}

When English is learnt by a community of profession, the community does not need to learn all variations of English or General English. They learn English they need in the work field. This activity of teaching and course designing is discussed in ESP (English for Specific Purposes) field. Dudley-Evans and St John (1998) in Basturkmen (2010: 13) state that one of the absolute characteristics of ESP is the teaching and learning process is designed to meet specific needs of learners. Therefore, it is important to conduct a needs analysis. Correspondingly, Basturkmen (2010: 17) defines the term needs analysis as a stage in which the course developer identify what specific language and skills the group of language learners will need. In addition, Basturkmen (2010: 19) lists the areas of needs analysis in ESP. It involves: 1) target situation analysis: identification of tasks, activities and skills learners are/ will be using English for, 2) discourse analysis, 3) present situation analysis, 4) learner factor analysis, and 5) teaching context analysis: identification of factors related to the environment in which the course will run.

\section{English for Nursing}

Related to the English usage in nursing, English is used in nursing documentation and communicating with the person (patient and other health professionals) at the fieldwork (Parkinson and Brooker, 2004). Therefore, the curriculum for English for Nursing in Nursing Academy of Ngawi District, Indonesia, is designed by AIPViKI (Asosiasi Institusi Pendidikan Vokasi Keperawatan Indonesia/ Association of Nursing Vocational Education Institutions of Indonesia) based on the needs of the nurses in the work field. Especially, the nurse needs speaking skills to build relationship both among the health professionals and between the nurse and the patients by using oral communication. There are two main functions of oral communication in nursing world; they are: for building relationship and for filling in chart, blanks, or nursing documentation (Parkinson and Broker, 2004).

\section{Listening}

Listening is one of receptive skills in learning language. In this research, the students are gathered to be familiar with the language through some tasks in the material. Related to the tasks that can be arranged as classroom performances, Brown (2007: 308) lists some classroom listening performances. They are: 1) reactive, it means the students simply listen to surface structure of an utterance and the students do not generate the meaning of the utterances, 2) intensive, it is the listening activity that focus on component of discourse, 3 ) responsive, it consists of short stretches of teacher language designed to elicit immediate responses, 4) selective, it means the students only focus on some important information embedded in the material, 5) extensive, it means the students derive a comprehensive message or purposes in the materials, and 6) interactive, it means the activities involved the above types of listening performances. In addition, Harmer (2007) presents some model of task sequences in listening activities. Those activities involve some skills in listening, such as predicting, listening specific information, listening for details, listening for gist, listening for general information, re-telling information, listening for language study, listening for acting out, interpreting text, and analysing language. 


\section{Speaking}

Talking about the activities in speaking class, Brown (2007) list some types of classroom speaking performance; they are: 1) imitative, it means the learners try to pinpoint some particular element of language form), 2) intensive, it means practising some phonological or grammatical aspect of language, 3) responsive, it refers to short replies to teacher or students initiated question or comment, 4) transactional (dialogue), it carried out for the purpose of conveying or exchanging specific information, 5) interpersonal (dialogue), it carried out more for the purpose of maintaining social relationship, and 6) extensive (monologue), it refers to some monologue practises, such as oral report, summaries, or short speeches.

\section{Task-Based Language Teaching (TBLT)}

Shehadeh in Edwards and Willis (2005:18) defines a language learning task as an activity that has a non-linguistic purpose or goal with a clear outcome and that uses any or all of the four language skills in its accomplishment by conveying meaning in a way that reflects real-world language use. Additionally, Prabhu (1987) in Ellis (2003) defines a task as an activity which required learners to arrive at an outcome from given information through some process of thought, and which allowed teachers to control and regulate that process. There are some task classification proposed by Ellis (2003), they are: pedagogic, rhetorical, cognitive, and psycholinguistic tasks. In addition, Pattison (1987) in Nunan (2004: 57) sets out seven task and activity types, they are: 1) questions and answers, 2) dialogues and role plays, 3) matching activities, 4) communication strategies, 5) pictures and picture stories, 6) puzzles and problems, 7) discussions and decisions.

Talking about the procedures in administering a task-based language classroom, Willis (1996) gives the framework that the phases of TBLT involve the process and activities in pre-task phase, task cycle, and language focus. Talking about the materials, there is no a blue print or example of the task based learning materials since any input can be used in a task-based class. Teachers can use either authentic or inauthentic materials with the criteria proposed by Willis (1996: 1), consisting of: exploitability, 2) topic variety 3) length, 4) linguistic complexity, 5) accessibility, and 6) copyright.

\section{Materials Development in English Language Teaching}

With regard to this research which is ESP, Dudley-Evans and St. John (1998) suggest that for teachers of ESP courses, materials serve functions as a source of language, as a learning support, for motivation, and stimulation, and for reference. In a more detail way, Cunningsworth (1995: 135) proposes the checklist for ESP materials, which some of them are elaborated as follows: 1) the materials are based on a careful analysis of learner needs, 2) the objectives are specified in content terms or in performance terms, 3) the content is appropriate to learners' needs, 4) there is a body of 'core' specialist language related to the subject area, 5) learners are equipped with skills and strategies which will allow them to operate effectively in English in the professional/ occupational situation, and 8) the way learning activities mirror real-life situations, e.g. through task-based and skill-based activities. 


\section{Review of Related Researches}

There are plenty research discussing English for Nursing. The first reviewed research is 'Developing Teaching and Learning Instrument of English for Nursing 'Daily Communication in Nursing' through Contextual Approach Based on Character Education' conducted by Mulyadi (2014). This research aims to develop teaching and learning instrument of English for Nursing for daily communication through contextual approach based on character education. The second reviewed research is 'The Role of Need Analysis in Teaching ESP for Nursing', conducted by Mitra (2014). This study reveals any information about the nurses' capacity and characteristic, the responsive program which is expected, and the improvement goal. The third reviewed research is 'Designing ESP Materials for Nursing Students Based on Needs Analysis' conducted by Saragih (2014). The study aims at exploring the learning needs of 50 nursing students, and designing ESP materials for nurses based on need analysis. The fourth reviewed research is 'Developing Instructional Materials on English Oral Communication for Nursing Schools', conducted by Sismiati and Latief (2012). In this study, they develop a textbook for speaking based on the principles of ESP and CTL learning theory. The textbook can be used as one of the sources of teaching materials for intermediate-to-advanced speaking classes and graduates wishing to apply for jobs abroad.

\section{Methodology}

The research subjects were second semester students of Nursing Academy of Ngawi District, East Java, Indonesia. The topic of this research was developing listening-speaking materials for nursing academy students so that it was classified as educational Research and Development. Gall and Borg (1983: 772) explain that R\&D is a process used to develop and validate educational products. There were some procedures conducted in this research. First, the researcher conducted needs analysis. After that, the researcher designed and developed the prototype of the material. Then, the draft was validated to some experts. The last steps involved trying out, evaluating, and revising the draft. The procedures are elaborated in Figure 1.

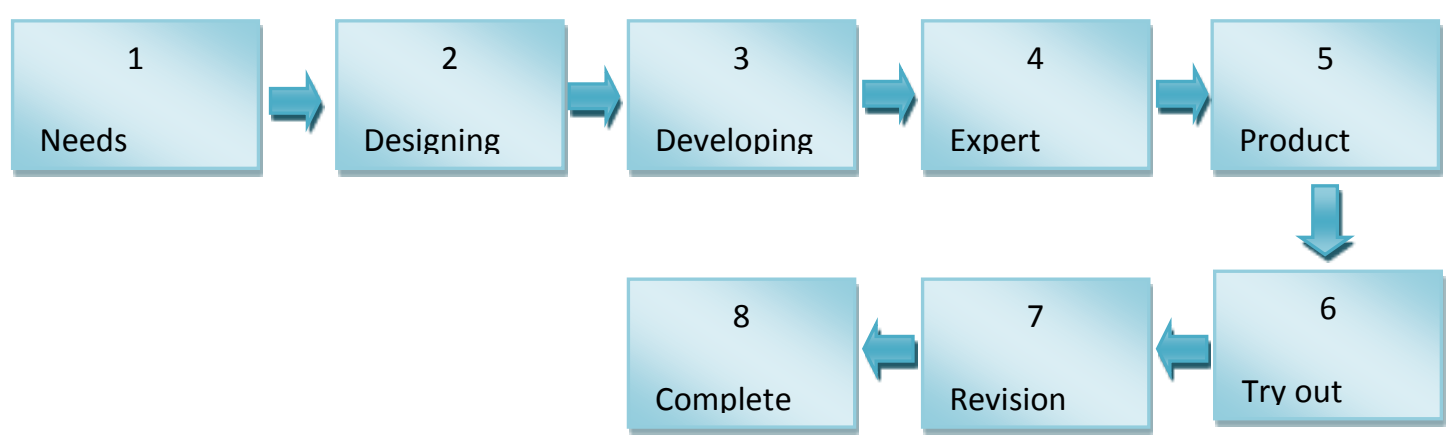

Figure 1 Research Process

Data collecting techniques involved questionnaires, interviews and observation. There were three questionnaires used in this research: questionnaire for needs analysis, questionnaire for expert judgement, and questionnaire for first try out. The interview and observation were conducted at 
first and second try out. The questionnaire for needs analysis was adapted from needs analysis checklist proposed by Hutchinson and Waters (1987) and Dudley-Evans and St John (1998) in Basturkmen (2010:18). The questionnaire for expert validation was organized based on the components of module evaluation proposed by Cunningsworth (1995:135). The aspects of materials evaluation involved content, presentation, illustration, language and graphic appropriateness. Then, the questionnaire for the students at try out was for finding out the effectiveness of the module.

After that, the data from questionnaires of needs analysis and try out were analysed through calculating the percentage of each answer on the questionnaires. The questionnaires for expert validation were calculated by using Likert-Scale as the measurement. Especially, the results of the questionnaire for expert validation then were converted by using the formula proposed by Suharto (2006: 52 - 53), which is presented in Table 1.

Table 1 Data Conversion Table

\begin{tabular}{lll}
\hline Scales & Interval & Descriptive Categories \\
\hline 1 & $2.9<\mathrm{X} \leq 3.24$ & Poor \\
\hline 2 & $3.25<\mathrm{X} \leq 3.49$ & Fair \\
\hline 3 & $3.5<\mathrm{X} \leq 3.74$ & Good \\
\hline 4 & $3.75<\mathrm{X} \leq 4$ & Very Good \\
\hline
\end{tabular}

\section{Findings}

This study was aimed at describing the existing listening-speaking materials used in English for Nursing subject in nursing academy and finding out the feasibility of the developed English listening-speaking materials for nursing academy students. The findings would be discussed respectively.

From the document analysis, it was found that there was no module that suited the curriculum applied in Nursing Academy of Ngawi District. Second, the existing books provided in the library were not equipped with audio or video materials which were useful to serve the students exposures for learning English for Nursing, especially for listening and speaking skill. Third, the conversation model provided in the book was too long and there was no emphasis to the English expression embedded in the conversation. Talking about the syllabus, the syllabus of English for Nursing Subject in Nursing Academy of Ngawi District was designed by the academic department of AIPViKI (Asosiasi Institusi Pendidikan Vokasi Keperawatan Indonesia/ Association of Nursing Vocational Education Institutions of Indonesia) for regional six. The syllabus was not equipped with learning materials. Therefore, the students and lecturer needed materials, especially for listening and speaking skills.

\section{Results of Needs Analysis}

Then, the researcher conducted a need analysis to gain information in developing the materials. The needs analysis involved present situation analysis, learners' factor analysis, objective needs, target situation analysis, materials components, and learning needs. First, present 
situation analysis was related to present students' existing proficiency, especially in listening and speaking skills. The result was presented in table 2. It is shown that in average, the students' proficiency was fair. Especially, they were good in introducing themselves and others based on their own duties.

Table 2 Students' Existing Proficiency in Listening and Oral Communication

\begin{tabular}{|c|c|c|}
\hline The Purpose of Question & Items & ondition \\
\hline $\begin{array}{l}\text { To find out the students' existing } \\
\text { proficiency in listening }\end{array}$ & The students listen to dialogue about health. & less \\
\hline \multirow{12}{*}{$\begin{array}{l}\text { To find out the students' existing } \\
\text { proficiency in } \\
\text { communication }\end{array}$} & Health professionals and their duties & fair \\
\hline & $\begin{array}{l}\text { Introducing themselves and others based on their own } \\
\text { duties in English }\end{array}$ & good \\
\hline & Parts of body and the function & fair \\
\hline & Handling patients' complain in English & fair \\
\hline & Wards and departments in a hospital & fair \\
\hline & Giving directions using hospital setting in English & fair \\
\hline & Hospital tools and the function & fair \\
\hline & Arranging the contract in health service setting & fair \\
\hline & Examining the patients & fair \\
\hline & Describing the patients' characteristics & fair \\
\hline & $\begin{array}{l}\text { Maintaining communication with patients in examining } \\
\text { patients }\end{array}$ & fair \\
\hline & Reporting the result of patients' examination & fair \\
\hline
\end{tabular}

After that, the researcher conducted students' factor analysis. It was related to students' interest in learning English for Nursing, students' difficulties in learning English for Nursing, vocabularies needed in learning English, preferred learning activities to learn new vocabularies, and needs of vocabulary list in the designed material. The result is presented in Table 3.

Table 3 Students' Factor Analysis

\begin{tabular}{ll}
\hline Purpose of Question & Result \\
\hline $\begin{array}{l}\text { To find out students' interest in learning English } \\
\text { for Nursing }\end{array}$ & $\begin{array}{l}\text { Most of the students (51\%) were interested in } \\
\text { learning English for Nursing and 31\% of them were } \\
\text { very interested in learning English for Nursing. }\end{array}$ \\
\hline $\begin{array}{l}\text { To find out students' difficulty in learning } \\
\text { English for Nursing }\end{array}$ & $\begin{array}{l}\text { Students mostly find difficulties because they did not } \\
\text { know the meaning of new word }(85,1 \%), \text { they found } \\
\text { difficulties in pronouncing the word correctly } \\
(63,4 \%), \text { and in writing sentences }(63,4 \%) .\end{array}$ \\
\hline $\begin{array}{l}\text { To find out vocabularies needed by the students } \\
\text { in learning English. }\end{array}$ & $\begin{array}{l}\text { Students needed both vocabularies in English for } \\
\text { Nursing }(83 \%) \text { and general vocabularies }(91 \%) .\end{array}$ \\
\hline $\begin{array}{l}\text { To find out preferred learning activities to learn } \\
\text { new vocabularies }\end{array}$ & $\begin{array}{l}\text { There were } 80 \% \text { of the students preferred to use } \\
\text { media (pictures, graphic, and realia) and applying } \\
\text { the vocabularies in dialogue and sentences to learn } \\
\text { new vocabularies. }\end{array}$ \\
\hline $\begin{array}{l}\text { To find out the need of vocabulary list in the } \\
\text { designed materials }\end{array}$ & $\begin{array}{l}\text { Most of the students (99\%) needed vocabulary list in } \\
\text { the designed materials. }\end{array}$ \\
\hline
\end{tabular}


In terms of goals, the tendency showed that $74 \%$ of the students claimed that to be able to speak correctly was their main objective in learning English for Nursing. Talking about topics, there were many topics listed in the syllabus of English for Nursing 1. Because of the research feasibility, the researcher only focused on several topics which were needed most by the students. As health professionals, some skills the students needed most were: examining the patients $62(\%)$, handling patient's complain (58\%), and maintaining communication with patients in examining patients $(52 \%)$. Then, the preferred components of the designed material included 1) unit title, 2) list of difficult words and the pronunciation, 3) explanation about vocabularies, 4) task for practicing the using of vocabularies in the context, 5) list of expressions in English for nursing, 6) example of dialogue between nurse and patient, 7) task for composing dialogue, 8) practising dialogue, and 9) self-assessment.

The last analysis was learning needs. It was related to learning sequence needed by the students, preferred learning activities, effective learning style, preferred grouping, input for learning English for Nursing orally, and length of dialogue text needed for learning English for Nursing orally. The result was presented in Table 4.

Table 4 Learning Needs

\begin{tabular}{ll}
\hline Purpose of Question & Result \\
$\begin{array}{l}\text { To find out preferred learning } \\
\text { activities }\end{array}$ & $\begin{array}{l}\text { The students prefer to learn by listening to } \\
\text { lecturer's explanation (71\%), discussion among } \\
\text { students }(57 \%) \text {, and practicing dialogue (50\%). }\end{array}$ \\
\hline $\begin{array}{l}\text { To find out the effective learning } \\
\text { style }\end{array}$ & $\begin{array}{l}\text { The students prefer to learn from reading (71\%) } \\
\text { and listening (59\%). }\end{array}$ \\
\hline To find out the preferred grouping & $\begin{array}{l}\text { The students prefer to learn in a small group (65\%) } \\
\text { and in pairs (58\%). }\end{array}$ \\
\hline $\begin{array}{l}\text { To find out the input for learning } \\
\text { English for Nursing orally. }\end{array}$ & $\begin{array}{l}\text { The students (81\%) prefer dialogue as the input for } \\
\text { learning English for Nursing orally. }\end{array}$ \\
\hline $\begin{array}{l}\text { To find out the length of dialogue } \\
\text { text needed for learning English for } \\
\text { Nursing orally }\end{array}$ & $\begin{array}{l}\text { Most of the students (44\%) prefer text with less } \\
\text { than } 100 \text { words for dialogue text. }\end{array}$ \\
\hline
\end{tabular}

\section{Task Development}

The material was developed based on the result of needs analysis. Talking about the content of the unit, it was found that the skills the students need most were: examining the patients, maintaining communication with patients in examining patients, and handling patients' complain. The researcher then arranged the topic based on the difficulty level and syllabus. Finally, there were three units materials which were developed based on the preferred topics. The researcher put 'handling patient' complaint' at the first unit (as the part of patients' admission process), 'examining patient' at second unit, and 'maintaining communication in examining patients' at third unit. The development of task was presented in Table 5 and the development of each chapter was visualized in Figure 2. 
Table 5 Task Development

\begin{tabular}{|c|c|c|c|}
\hline Components & Unit 1 & Unit 2 & Unit 3 \\
\hline Title & $\begin{array}{l}\text { Can I Ask You Some } \\
\text { Questions for Admission, } \\
\text { Mrs. Ambar? }\end{array}$ & $\begin{array}{l}\text { What Brought You Here } \\
\text { Today? }\end{array}$ & Can You Flex Your Toes? \\
\hline $\begin{array}{l}\text { Basic } \\
\text { Competence }\end{array}$ & $\begin{array}{l}\text { Students are able to ask } \\
\text { questions for patients' } \\
\text { admission. }\end{array}$ & $\begin{array}{l}\text { Students are able to ask } \\
\text { questions for completing } \\
\text { medical records. }\end{array}$ & $\begin{array}{lcc}\begin{array}{l}\text { Students are able } \\
\text { questions } \\
\text { assessment }\end{array} & \text { tor ask } \\
\text { physical }\end{array}$ \\
\hline Task & $\begin{array}{l}\text { completing a chart, } \\
\text { matching meaning of } \\
\text { words, analysing true and } \\
\text { false statement, practicing } \\
\text { dialogue, completing } \\
\text { patient's admission data }\end{array}$ & $\begin{array}{l}\text { answering question for } \\
\text { digging up background } \\
\text { knowledge, listing, } \\
\text { matching, practicing } \\
\text { dialogue of patient } \\
\text { assessment. }\end{array}$ & $\begin{array}{l}\text { matching words with meaning, } \\
\text { completing the dialogue, } \\
\text { practicing the instruction in } \\
\text { physical assessment }\end{array}$ \\
\hline
\end{tabular}

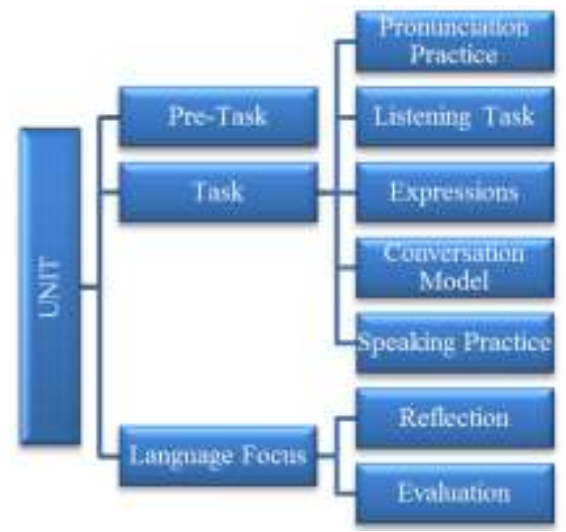

Figure 2 Development of Each Unit

\section{Expert Validation}

The means of all materials evaluation aspects show that the materials are good to be used by nursing academy students. However, there were still some parts that need to revise. In terms of content, the experts suggested that there should be more attention getter in Get Ready Task. In terms of presentation, the experts suggested that the task must be balance in each topic. In terms of illustration, the experts suggested that the illustration pictures must be Indonesian people. In terms of language appropriateness, the researcher had to revise the long instruction in to simple instruction. In terms of graphic, the experts suggested the researcher to make the font size smaller. Lastly, the materials was validated as shown in Table 6.

Table 6 Materials Validation

\begin{tabular}{lcccccc}
\hline \multirow{2}{*}{$\begin{array}{l}\text { Components of } \\
\text { Evaluation }\end{array}$} & Materials & \multicolumn{2}{c}{ Unit 1 } & \multicolumn{2}{c}{ Unit 2 } & \multicolumn{2}{c}{ Unit 3 } \\
\cline { 2 - 7 } & Mean & Category & Mean & Category & Mean & Category \\
\hline Materials appropriateness & 3,9 & Very Good & 3,9 & Very Good & 3,9 & Very Good \\
\hline Presentation appropriateness & 3,8 & Very Good & 3,9 & Very Good & 3,7 & Good \\
\hline Illustration appropriateness & 3,7 & Good & 3,7 & Good & 3,7 & Good \\
\hline Language appropriateness & 3,8 & Very Good & 3,8 & Very Good & 3,8 & Very Good \\
\hline Graphic appropriateness & 3,8 & Very Good & 3,9 & Good & 3,8 & Very Good \\
\hline
\end{tabular}




\section{Try Out}

After materials validation, the researcher tried out the listening-speaking materials to the students. In general, the students were able to actively join the lesson. The try out result also showed that the module was considered effective for helping the students to practise the expressions in English for Nursing. As presented in Table 7, each materials component was effective to help the students in learning, especially in practising the expressions in English for nursing, learning new vocabularies, and monitoring their own learning progress. The components of evaluation consisted of the effectiveness of unit title, Get Ready Task, pronunciation practice, listening task, speaking practice, evaluation, and vocabulary list. Most of the students were agree with the statements that those components were effective to help the students in learning English for Nursing, especially in listening and speaking skills.

Table 7 Try Out Result

\begin{tabular}{lcccccc}
\hline \multicolumn{1}{c}{ Components of evaluation } & \multicolumn{2}{c}{ Unit1 } & \multicolumn{2}{c}{ Unit 2 } & \multicolumn{2}{c}{ Unit 3 } \\
\cline { 2 - 7 } & $\mathbf{A}(\%)$ & $\mathbf{D}(\%)$ & $\mathbf{A}(\%)$ & $\mathbf{D}(\%)$ & $\mathbf{A}(\%)$ & $\mathbf{D}(\%)$ \\
\hline $\begin{array}{l}\text { The unit title helps the students to predict the topic } \\
\text { that will be discussed }\end{array}$ & 95 & 5 & 86 & 14 & 92 & 8 \\
\hline $\begin{array}{l}\text { Get Ready Task is effective to make the students be } \\
\text { prepared for learning }\end{array}$ & 90 & 10 & 88 & 12 & 94 & 6 \\
\hline $\begin{array}{l}\text { Listening Task is effective to help the students to } \\
\text { understand the using of English in nursing context. }\end{array}$ & 94 & 6 & 95 & 5 & 86 & 14 \\
\hline $\begin{array}{l}\text { Pronunciation Practice is effective to help the } \\
\text { students in pronouncing the words correctly. }\end{array}$ & 95 & 5 & 94 & 6 & 90 & 10 \\
\hline $\begin{array}{l}\text { Speaking Practice is effective to help the students to } \\
\text { practise the expressions. }\end{array}$ & 95 & 5 & 88 & 12 & 86 & 14 \\
\hline $\begin{array}{l}\text { Evaluation is effective to monitor the students' } \\
\text { learning progress. }\end{array}$ & 90 & 10 & 95 & 5 & 92 & 8 \\
\hline $\begin{array}{l}\text { Vocabulary List is effective help the students to } \\
\text { remember the new words. }\end{array}$ & 95 & 5 & 92 & 8 & 90 & 10 \\
\hline
\end{tabular}

$\begin{array}{ccl}\text { Note } & : \text { A } & \text { : Agree } \\ & \mathrm{D} & \text { : Disagree }\end{array}$

\section{Discussion}

Regarding the research findings described in the previous section, some of the findings should be discussed. This section covered the analysis of research findings and the relation with the result of previous studies. First a needs analysis has been conducted based on the theories proposed by Hutchinson and Waters (1987) and Dudley-Evans and St John (1998) in Basturkmen (2010:18). In this part, the researcher collected some information related to present situation, learners' factors, objective needs, target situation, materials components, and learning needs.

After that, in materials development, the researcher referred to some theories for both composing and searching input for reading and writing. For example, in presenting the expressions in English for Nursing, the researcher referred to list of expressions proposed by Parkinson and Broker (2004), involving: a) getting started, which is the nurse needs to say the name and why she is there, b) the nurse should ask about patient's biographical data, c) asking about reason for 
admission or contact with health services and medical details, and d) asking about lifestyle. For vocabularies or medical terminologies that must be mastered by the nurses, the researcher referred to the list of medical terminologies proposed by Parkinson and Brooker (2004: 60). Additionally, the researcher also referred to lists of activities in undertaking the English for medical purposes proposed by Ferguson (2013) that involved simulated case conferences and role play.

This research project is one of the researches conducted in English for Nursing world. Similar to the research conducted by Mitra (2014) the needs analysis in this research was important to gain some information about learners' capacity and characteristics. This research also revealed that the learners found difficulties in communication and documenting. However, the output of research conducted by Mitra (2014) was courses for nurses, while the output of this research is a module for learning English for Nursing. Talking about the product, the materials of English for Nursing developed by Sismiati and Latief (2012) and Mulyadi (2014) were designed based on Contextual Approach, while the module developed in this research were designed based on TBLT approach. The variation was good to enrich the model of English for Nursing materials. Talking about the product content, materials developed by Saragih (2014) and Sismiati and Latief (2012) focused only on speaking skill while the product of this research involved listening and speaking skills.

This material was designed based on TBLT, in which, the stage in teaching and learning process was divided into these phases: Pre-Task, Task, and Language Focus. At Pre-Task Phase, the researcher gave task for digging background knowledge about the topic. Figure 3 below is the Pre Task activity for unit 1.

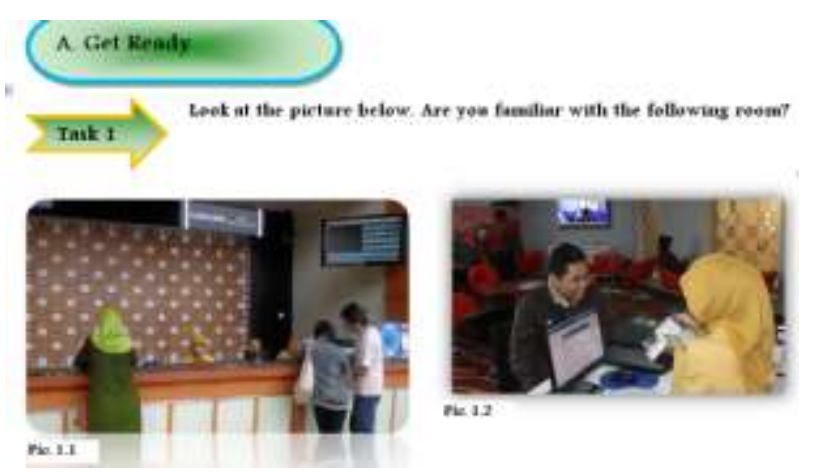

Figure 3 Giving Background Knowledge in Get Ready Task

Next is the main listening task. In this task, the students had to find some information embedded in the audio material. According to Brown (2007), it belongs to selective listening performance. The example is presented in Figure 4. 


\section{B. Let's Listen and Speak}

\section{Task 4}

Listen to the unrse gets personal details from a patient. After that, makk the following statements True $(T)$ or False (F).
a. The nurse has already known the patient's name.
b. The patient comes to the hospital for an operation.
c. The patient ever has pneumonia two years ago.
d. The patient takes aspirin every day because she has got a headache.
e. The patient has never got any operation betore.
f. The patient is allergic to nuts.
8. Paula is Susan's mother.

Figure 4 Main Listening Task

Listening Task could be used as a model for speaking task. However, in this material, the researcher also provided lists of useful expressions for nurse-patient communication. Figure 5 is the example of useful expressions for patients' admission.

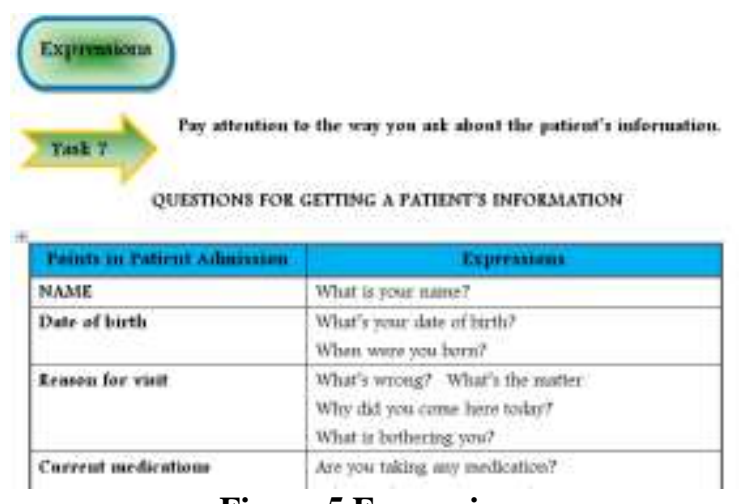

Figure 5 Expressions

Then, Figure 6 is the example of main speaking task. In this case, the students must compose and practise dialogue based on the topic. In this example, the students have to compose and practise a dialogue about patients' admission.

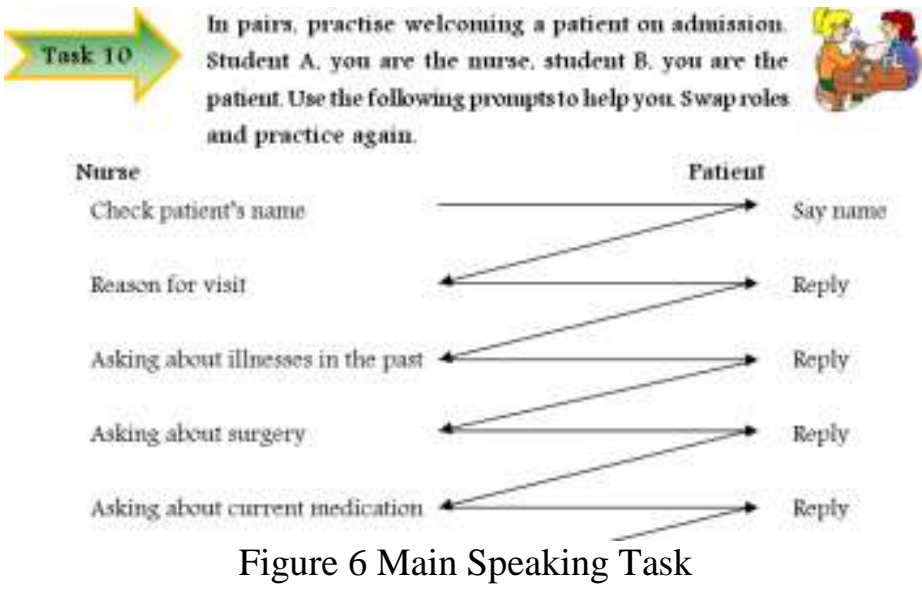


After accomplishing the task, the students measure their own competence in doing the task. There are reflection and evaluation parts. The evaluation is in the form of practicing dialogue and it would be marked by the teacher by using rubrics of speaking assessment. The example of evaluation is Figure 7.

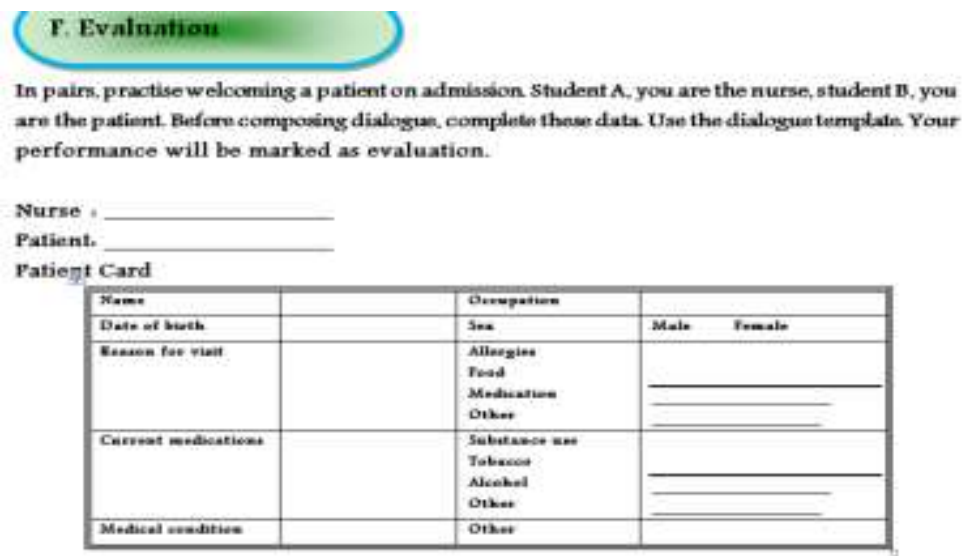

Figure 7 Evaluation

After conducting all process in materials development, the researcher highlighted some important and valuable points in this research type. First, needs analysis was very important to gain the information about learners and their needs about English language learning. Second, arranging and grading tasks were challenging activities since the researcher had to pay attention to the objective, input, difficulty level, and length of the task. Third, the experts' evaluation and suggestion and students' responses in try out were very important for the researcher to develop a good and valuable module.

Finally, the result of this research was listening-speaking materials of English for Nursing with following characteristics: 1) it was designed based on TBLT principles, 2) it was developed based on students' needs, 3) it contained tasks that enabled the students to learn and practise the language they needed in their workplace, 4) it consisted of four chapters with the theme chosen by the students, 5) the objectives were clearly stated in each chapter, and 6) it was equipped with audio materials for listening exercises.

\section{Conclusion and Suggestion}

First, talking about the existing materials for teaching English for Nursing subject, it is found that there was no material that suited the curriculum applied in Nursing Academy of Ngawi District and the existing books provided in the library were not equipped with audio or video materials. Then, needs analysis was conducted to gain the information to design and develop the materials. The researcher only focused on several topics chosen by the students. Finally, the developed materials consisted of three chapters. The feasibility of the developed materials was gained through experts' validation and try out. The suggestions proposed by the experts and the results of try out were put up to develop feasible materials for teaching English for Nursing, especially for listening and speaking skills. 
The result of this research, listening-speaking materials of English for Nursing subject, was expected to be beneficial for the following stakeholders: 1) English lecturer at Nursing Academy, as the one who knows the students' needs and background, it is suggested that the English lecturer of Nursing Academy develops his/ her own materials for the students based on the needs analysis, and 2) other materials developer. The first suggestion is that the most important key in developing materials is needs analysis. Secondly, considering students' background knowledge and recent ability are also essential in developing ESP materials.

\section{References}

AIPViKI (2015). Kurikulum Akademi Keperawatan. Retrieved from https://aipvikijatim.wordpress.com/tag/aipdiki-jatim/ in March 17th 2015.

Basturkmen, Helen. 2006. Ideas and Options in English for Specific Purposes. New Jersey: Lawrence Erlbaum Associates Publishers.

Basturkmen, Helen. 2010. Developing Courses in English for Specific Purposes. Hampshire: Palgrave Macmillan.

BNP2TKI .2015. Pendaftaran Calon Nurse dan Careworker. Retrieved from http://www.bnp2tki.go.id/gtog_jepang/indeks in April 1st 2015.

Brown, H. Douglas. 2007. Teaching by Principles (3 ${ }^{\text {rd }}$ edition). New York: Longman Limited.

Cunningsworth, Alan. 1995. Choosing Your Course Book. Oxford: Macmillan Publishers Limited.

Dudley-Evans, Tony and M. J. St. John. 1998. Developments in English for Specific Purposes: A Multi-Disciplinary Approach. Cambridge: Cambridge University Press.

Ellis, Rod. 2003. Task-based Language Teaching and Learning. New York: Oxford University Press.

Ferguson, Gibson. 2013. English for Medical Purposes in B. Paltridge and Sue Starfield (eds). The Handbook of English for Specific Purposes. Sussex: Wiley-Blackwell.

Gall, Meredith D. and Walter R. Borg. 1983. Educational Research: An Introduction (4 ${ }^{\text {th }}$ edition). New York: Longman.

Harmer, Jeremy. 2007. The Practice of English Language Teaching. London: Pearson.

Hutchinson, Tom and Alan Waters. 1987. English for Specific Purposes. Glasgow: Cambridge University Press.

Mitra, M. Mujtaba. 2014. The Role of Need Analysis in Teaching ESP for Nursing in the $61^{\text {st }}$ TEFLIN International Conference 2014 Proceedings. Surakarta: English Department, Teacher Training and Education Faculty, Sebelas Maret University. 
Mulyadi, Dodi. 2014. Developing Teaching and Learning Instrument of English for Nursing Daily Communication in Nursing through Contextual Approach Based on Character Education in $61^{\text {st }}$ TEFLIN International Conference 2014 Proceedings. Surakarta: English Department, Teacher Training and Education Faculty, Sebelas Maret University.

Nunan, David. 2004. Task-Based Language Teaching. Cambridge: Cambridge University Press

Parkinson, Joy and Chris Brooker. 2004. Everyday English for International Nurses: A Guide to Working in the UK. London: Churchill Livingstone.

Saragih, Erikson. 2014. Designing ESP Materials for Nursing Students Based on Needs Analysis. International Journal of Linguistics, 6 (4), 59-70. doi:10.5296/ijl.v6i4.5983.

Sismiati and Mohammad Adnan Latief. 2012. Developing Instructional Materials on English Oral Communication for Nursing School. TEFLIN Journal, 23(1), 44-59, January 2012.

Suharto, G. 2006. Penilaian Pembelajaran Bahasa Inggris. Yogyakarta: P2B UNY.

Willis, Jane. 1996. A Framework for Task-Based Learning. Essex: Addison Wesley Longman Limited.

\section{Copyrights}

Copyright for this article is retained by the author(s), with first publication rights granted to the journal.

This is an open-access article distributed under the terms and conditions of the Creative Commons Attribution license (http://creativecommons.org/licenses/by/4.0/). 